\title{
The Contribution of Family Factors to Dropping Out of School in Greece
}

\author{
Olympia Tsolou, Thomas Babalis \\ Department of Primary Education, National \& Kapodistrian University, Athens, Greece \\ Email: olympiatsolou@gmail.com
}

How to cite this paper: Tsolou, O., \& Babalis, T. (2020). The Contribution of Family Factors to Dropping Out of School in Greece. Creative Education, 11, 1375-1401. https://doi.org/10.4236/ce.2020.118101

Received: July 14, 2020

Accepted: August 23, 2020

Published: August 26, 2020

Copyright $\odot 2020$ by author(s) and Scientific Research Publishing Inc. This work is licensed under the Creative Commons Attribution International License (CC BY 4.0).

http://creativecommons.org/licenses/by/4.0/

\begin{abstract}
The current study was aimed at addressing the problem of dropping out of school in Greece and at finding out the specific social-family factors that have a significant impact on Greek students' decision to leave school early. Furthermore, the particular students' characteristics that potentially put them at risk and lead to their dropping out of school were drawn up through the present study. To that end, quantitative research through the use of a student questionnaire was carried out among one thousand five hundred twenty-eight (1528) students (799 boys and 729 girls) in various schools in Greece. The research results showed the presence of certain family factors that contributed towards Secondary School dropping out, the major ones being parental professional encouragement, parental school help, parental support in low school performance, parental encouragement for optimal effort, parental knowledge of children's social life and the frequency of parents' visits to school and their corresponding informing by teachers.
\end{abstract}

\section{Keywords}

School, Dropping Out, Factors, Family

\section{Introduction}

Dropping out of school is a multi-factorial and multi-leveled phenomenon, which has been the subject of and associated with decades of much research, speculation and controversy. Early leaving is characterized as a long-term process of disengagement from school and school life in general, which can be traced back even in the first grades of primary school (Finn, 1989). A student's decision to drop out of school is explained not only by one and only factor but by a combination of convergent and divergent causes which are put forward, including individual, family, school and social parameters (Arum \& Velez, 2012; 
Houssemand \& Meyers, 2013; Kotok, Ikoma, \& Bodovski, 2016).

Two groups of contributing factors to the phenomenon of dropping out are acknowledged in global literature (Allaire, Michaud, Boissonneault, Cote, \& Diallo, 2005; Coyle, 2009; Ratelle, Guay, Vallerand, Larose, \& Senecal, 2007; Rumberger \& Lim, 2008; Rumberger, 2011):

1) Factors that are associated with the student's family and are referred to as Social/Family Factors: family's socio-economic status, race and ethnicity, siblings' poor academic performance, family mobility, lack of parental support and educational expectations, negative parental attitude or even ignorance on their part, absence of stability in family environment, single-parenting, job pursue, personal or social problems.

2) Factors that are associated with school, the student's individual characteristics and experiences and are referred to as School Factors: poor academic performance, truancy, absenteeism, discipline problems, involvement in fighting with schoolmates or teachers, prior poor academic performance, frequent changing of schools, lack of interest, negative school climate.

However, the focus of the present study is on the first group of factors and more specifically, on some of those family variables that are of pivotal importance in a student's decision to drop out of school.

Family constitutes the most influential agent among the different social factors, which affect the growth and development of a child (Chenge, Chenge, \& Maunganidze, 2017). According to Baldwin (2000), family is a powerful agent of a child's socialization and the importance of the quality of the parent-child bonding process has been widely acknowledged. Parents' economic and educational status, family structure, their cultural and ecological profile, the relationship and the interaction among its members, their values and beliefs are some of the variables that render family environment as an agent of education and influence on a child's academic performance (Christenson, Rounds, \& Gorney, 1992; Steinberg, Dornbusch, \& Brown, 1992; Banks, 2006; Gandara \& Contreras, 2009; Rumberger, 2011; Farrington, Roderick, Allensworth, Ngaoka, Keyes, Johnson, \& Beechum, 2012; Bloom \& Unterman, 2014). Both statistical and empirical research have concluded that the children who come from better family environments do not run the risk of leaving school early as much as those coming from poorer-in all aspects-family environments (Hunt, 2008).

The variables that comprise a child's family environment (D'Agostino, 2000; Rumberger \& Lim, 2008; Ratcliffe \& McKernan, 2010) are parents' professional and educational characteristics, which make up a family's general socio-economic status, as well as their place in the stratification system, family structure, parent-child interaction and family cultural status.

The phenomenon of dropping out of school is rather new in Greek educational reality and researchers, teachers and parents have recently reflected on it, especially with the advent of the severe financial crisis Greece has been experiencing. Thus, the present study comes to fill in the gap in the existing Greek literature on the interaction of the aforementioned familial factors with specific stu- 
dents' characteristics, such as, their gender, nationality, school grade, and area of their school (urban, semi-urban, rural). Moreover, such a deep field research can be of great assistance to both students and teachers, so as to be more effective in their school performance and teaching respectively.

\section{Family Factors}

\subsection{Family Socio-Economic Status}

The social status and the inequalities created among the families, students come from, result in them also being unequal as far as their school performance is regarded. Families with low economic status have limited access to public and social benefits, including the benefit of education. Consequently, they are excluded both socially and educationally (Ratcliffe \& McKernan, 2010; Rumberger, 2011).

According to global literature (Ingels, Scott, Lindmark, Frankel, \& Myers, 1992; Perreira, Harris, \& Lee, 2006; Rumberger, 1995; Croninger \& Lee, 2001; Rumberger \& Lim, 2008; Ratcliffe \& McKernan, 2010), there are many ways to measure a family's social and financial status, with the most reliable one being Socioeconomic Status or SES (Rumberger, 2011: p. 190), which is a complex index, based on the various measures of a family's financial and human resources, such as parents' occupational status, education and income (Dalton, Gennie, \& Ingels, 2009; Osgood, Foster, \& Courtney, 2010; Rumberger, 2011; Tenbusch, 2016). Thus, research shows that students coming from families with high SES are less likely to leave school early (Davies \& Geoff, 1983; Ingels, Scott, Lindmark, Frankel, \& Myers, 1992; Rumberger \& Lim, 2008; Ratcliffe \& McKernan, 2010; Rumberger, 2011). Poverty is considered to be one of the most important causes of early school leaving (Bruneforth, 2006; Cardoso \& Verner, 2007, cited in Srivastava, 2012). High parental income makes it more possible for a family to provide more resources to support children's education, including access to better quality schools, private tuitions and more support for learning within home (Demaine, 1989; Coelho, 1998; Corson, 1998; Cardoso \& Verner, 2007; Braun \& Clarke, 2013; Chenge et al., 2017).

Further, a lot of researchers have pointed out the correlation between a family's social status and origin and their children's gender, as well as the effect of these variables on school performance (Murphy, 1981; Chapman, 1986; Roser, Hoffman, \& Farest, 1990; Jimerson, 1999; Ball, Davies, David, \& Reay, 2002; Hanafin \& Lynch, 2002; Tenbusch, 2016). In particular, girls coming from families of all social classes outweigh boys as far as their school performance is regarded, while girls coming from poor families are more likely to abandon school, with boys showing very poor school performance, as compared to those coming from families with a higher family income.

However, Coleman (1988) claimed that it is possible to have children who share the same family socioeconomic characteristics and, nevertheless, manifest differentiated school performance, a fact which is largely explained as being a result of the interaction of some other factors as well. Thus, there was a further 
distinction of family environment into three main constituents-family income, human capital (parents' education) and social capital (strong parent presence, parent-child quality time, their interpersonal relationship) (ibid., 1988, pp. 95-120).

Therefore, while family income can equip children with all the necessary resources for a proper education and human capital with a supportive environment which fosters learning, neither of them would be enough if it weren't for social capital, that is, meaningful time spent on parent-child interpersonal relationship, parental interest, support and encouragement. On the contrary, social capital itself can be an agent of learning, even if the other two parameters do not exist (Coleman, 1988; Toomey, 1989; Ratcliffe \& McKernan, 2010; Tenbusch, 2016). It is also known that poor families are not supportive of their children carrying on school, while wealthy families encourage them to extend and expand their studies, even if their individual potential is not high (Warren, LePore, \& Mare, 2000).

\subsection{Educational Background of Parents}

Various researchers come to an agreement regarding the direct association of parents' literacy level with children's academic achievement and their decision to leave school early (Hochschild \& Scovronick, 2003; Allaire, Michaud, Boissonneault, Cote, \& Diallo, 2005; Coyle, 2009; Ratelle, Guay, Vallerand, Larose, \& Senecal, 2007; Rumberger \& Lim, 2008; Rumberger, 2011).

It has been supported that a low literacy level leads to a vicious cycle of illiteracy (Chugh, 2011) and children coming from educated families are reported to show high academic achievement and educational attainment in all cognitive fields-writing, reading, Maths, to mention but a few, and tend to follow in the footsteps of their parents, resulting in being actively involved in their studies (Chevalier, Halmon, O'Sullivan, \& Walker, 2005; Bjorklund \& Salvanes, 2010; Menheere \& Edith, 2012). The higher parents' educational level is, the better children perform at school (Corson, 1998; Reese, Garnier, Gallimore, \& Goldenberg, 2000; Kober, 2001; Worswick, 2001). Better educated parents are claimed to have higher educational aspirations for their children as compared to those with a poor academic background, motivate their children's willingness to learn, guide and counsel them on the best way to successfully perform at school and provide them with the necessary resources needed, thus making a huge contribution to their school outcomes (Feinstein \& Symons, 1999; Bynner \& Joshi, 2002; Chevalier, Halmon, O’Sullivan, \& Walker, 2005; Oreopoulous, Page, \& Stevens, 2006; Lund, 2009).

\subsection{Family Structure}

The type of a family structure a child grows up in affects this child's decision to drop out of school. Home environment and family processes provide a network of physical, social and intellectual forces and factors that affect students' learn- 
ing. When referring to family structure, the number and the types of a family's members are pinpointed (Rumberger, 2011). Thus, different family structures include two-parent or nuclear families, single-parent families and foster families (Levin, 2012; Babalis, Xanthacou, \& Kaila, 2018). Various changes in a family's structure, such as divorce, separation, a spouse's death, family mobility are all variables that define change in a family structure and turn it from a nuclear family to a single-parent or foster one, while they are considered to be extremely stressful for all the members of a family, a fact that increases dropping-out rates (Astone \& McLanahan, 1991; Haveman, Wolfe, \& Spaulding, 1991; Day, 1993; Alexander, Entwisle \& Horsey, 1997; Garnier, Stein, \& Jacobs, 1997; Schargel \& Smink, 2001; Bohon, Garber, \& Horowitz, 2007; Babalis, Tsoli, Nikolopoulos, \& Maniatis, 2014).

In global literature, the effects of the changes in the structure of a contemporary family are regarded as detrimental to a child's emotional and social development (Seltzer, 1994). According to Garasky (1995), any changes in family structure taking place before the age of four have a positive effect on a child's likelihood of successful school completion, while changes occurring after the aforementioned age are reported to have negatively influenced the corresponding drop-out rates. Moreover, students who stopped living with both parents at the age of eight and started living with only one of them are more likely to leave school early (Pong \& Ju, 2000).

Furthermore, another important variable of a family's structure is its size. Families that consist of many members seem to invest fewer resources on children's education (Hunt, 2008). Researchers (Haveman, Wolfe, \& Spaulding, 1991; Alexander, Entwisle, \& Horsey, 1997; Garnier, Stein, \& Jacobs, 1997) that have studied the contribution of the family size as a variable-as this is defined by the number of children or the total number of its members-to dropping out rates, have concluded that children coming from large families are more likely to leave school early as compared to those of a smaller family (Osgood et al., 2010; Snyder \& Dillow, 2011). A possible explanation could be that children that belong to a small family are the happy recipients of parental interest and are mostly motivated to successfully complete their studies. On the other hand, in a large family, children are more likely to be forced to abandon their studies so as to take on more family responsibilities (house-keeping, looking after siblings) (Snyder \& Dillow, 2011).

\subsection{Family Cultural Status}

A family's cultural status is described as a compound notion of knowledge, ideas, values and attitudes that are cultivated in a family environment and constitute agents of promoting its members' intellectual growth and development (Rumberger \& Lim, 2008; Rumberger, 2011).

Several researchers have manifested the significance of cultural differences in the creation of different learning conditions for children who derive from dif- 
ferent socioeconomic backgrounds and cultural groups (D'Agostino, 2000; Rumberger \& Lim, 2008; Ratcliffe \& McKernan, 2010; Teklemariam, 2011). The cultural differentiation among families, resulting from their corresponding socioeconomic differentiation, has been used as a vehicle for the interpretation of issues related to the poor school performance of children coming from lower social class families that are reported to have a low cultural status as well.

Lower social class families create an environment deprived of the appropriate stimuli, so that their children's mental abilities and skills are not triggered and developed, since there is lack of their familiarization with culture, that is, music, literature, drama, museums, resulting in the underdevelopment of their cognitive and intellectual skills, which would help them perform better at school (Trang \& Van der Velden, 2011; Samal, 2012).

On the other hand, the children that come from powerful-in all aspects-families carry along the cultural capital, which is essential to their school success, since it is the same as that adopted by the school they attend. Special behavioral patterns, ways of speaking, dressing, inter personal interaction and communication, adopting an appropriate language code and a positive self-image are all parameters comprising the cultural capital that the children from families with low socioeconomic status are deprived of. Moreover, these deprived children seem to have limited access to important notions, issues and ideas that their school curriculum deals with, fail to successfully respond to the needs and requirements posed and finally abandon school (Delpit, 1988; Silva \& Kucer, 1997).

\subsection{Parent-Child Interaction}

It is widely accepted that the role parents perform on their children's educational growth and development is crucial and better academic outcomes are fostered through the fundamental family-school cooperation (Christenson \& Conoley, 1992; Chavkin, 1993; Kellaghan, Sloane, Alvarez, \& Bloom, 1993a; Fan \& Chen, 2001; Spera, 2005; Stone, 2006; Jeynes, 2007; Rumberger, 2011; Xanthacou, Babalis, \& Stavrou, 2013).

Parents monitor and regulate their children's activities, provide them with emotional support, encourage their independent decision-making and constitute a powerful socializing agent for them, equipping them with all the necessary "tools" for the process of personal change and growth they have to go through and helping them form a socially accepted behaviour as "this is dictated by the norms of the social group they belong in" (Child, 1972: p. 15).

In this framework, all the prerequisites for the formation of a child's social behavior in a given social circle are set (Henecka, 2001; Babalis, 2011) and his/her transition from the first socializing level to the second one, which is school, and his/her adaptation and/or acceptance by the school system are achieved. In particular, basic skills are cultivated in children, such as, conquering specific knowledge and skills (in their mother tongue for instance), the practical application of those skills and the development of emotions and motives (learn- 
ing aspirations, high self-esteem, motivation for successful school attainment and performance and completion of their studies).

Various researchers have defined this process using different terms. More specifically, parent-children relationship and interaction has been referred to as social capital by Coleman (1988), while others use the terms parental involvement or parenting style (Fan \& Chen, 2001; Spera, 2005; Stone, 2006; Jeynes, 2007). The aforementioned process of socialization is not the same for all families. There are families that promote the cultivation of attitudes, motives and learning skills in their children, while others act in an adverse way, resulting in bringing up children with low academic aspirations and unable to exploit their potential in such a way so as to come to a successful completion of their studies (Green, Walker, Hoover-Dempsey, \& Sandler, 2007).

The physical absence of parents due to various reasons, the limited amount of time parents and children spend together with the corresponding parental inattention to their children's activities and the lack of instillation of educational values to them have been reported as detrimental to a child's course towards successful school completion (Lichter, Gretchen, Cornwall, \& Eggebeen, 1993; Phares, 2010; Babalis \& Tsoli, 2017).

Several researchers have claimed that great parental expectations and their positive encounter and attitude minimize the risk of their children dropping out of school (Teachman, Paasch, \& Carver, 1997; Rumberger \& Thomas, 2000; Jacob, 2001; Stone, 2006; Rumberger \& Lim, 2008; Rumberger, 2011). According to Sanders and Epstein (2000), teenagers, though needing more independence than younger children, are in a greater need of parental guidance, support and caring. A trusting and supporting family environment, which promotes teenagers' autonomy, wards off any thoughts of dropping out of school (Kellaghan, Sloane, Alvarez, \& Bloom, 1993b; Deslandes, Potvin, \& Leclerc, 1999; Hill \& Taylor, 2004; Lloynd, Mete, \& Grant, 2009).

\section{Research Design}

\subsection{Participants}

A sample of one thousand five hundred twenty-eight (1528) students (799 boys-52.3\%; 729 girls, $47.7 \%$ girls) volunteered to participate in this study. Out of the total sample, one thousand three hundred and fifty-eight $(1358,88.9 \%)$ were indigenous students, and one hundred seventy $(170,11.1 \%)$ were foreign students. The students ranged in age from 13 to 15 years old and they were attending the $1^{\text {st }}$ Grade of Junior High School (575 students, 37.7\%), the $2^{\text {nd }}$ Grade of Junior High School (475 students, $31.1 \%$ ), and the $3^{\text {rd }}$ Grade of Junior High School (478 students, 31.3\%). Regarding the area of the schools the students were attending, one thousand one hundred and fifty-four $(1154,75.5 \%)$ students' schools were located in an urban area, seventy three $(73,4.8 \%)$ in a semi-urban area, and three hundred and one $(301,19.8 \%)$ students were attending a school situated in a rural area. 


\subsection{Instrument}

For the purposes of the study under scrutiny, an anonymous student questionnaire was constructed in the Greek language. The questionnaire construction was based on the social-familial factors influencing a child's decision to drop out of school, drawn up from the relevant literature on the phenomenon of early school leaving.

More specifically, the student questionnaire consisted of eight (8) questions, providing their responses in each item on a 5-point Likert scale, ranging from 1 representing "strongly disagree" to 5 referring to "strongly agree", with intermediate points of 2 repressing "disagree", 3 "neither agree or disagree" and 4 "agree".

The aim of the specific questionnaire was to examine the level of encouragement Greek students receive by their parents regarding their personal choice of a future profession and whether their parents enhearten them to pursue optimal performance at school by always doing their best in order to achieve their goals. Further, it was important to find out whether students were assisted in their schoolwork by their parents and supported in the event of low grades or/and a possible school failure. A critical research question was to find out the ways parents' interest in their children's progress is manifested. This could happen not only through frequent visits to school aiming at being informed about students' progress, but also through their awareness of their children's social life, either being negatively influenced by it or not.

\subsection{Procedure}

In the beginning, the researcher requested for permission to carry out the present study in the Districts of Aitoloakarnania and Attica in Greece and administer herself the questionnaires of the present study to the students of the corresponding schools. The schools were randomly selected based on a list provided by the Greek Ministry of Education, which was stratified based on gender and socioeconomic group (high, medium, low), in order to be representative of the demographic characteristics and status of the population. A parental consent was also required for the children to participate in the study.

Before the main data collection of the study, a pilot study was conducted to examine possible misunderstandings by the students. The researcher had to administer questionnaires to 20 students, who were randomly selected from various backgrounds-either personal or academic ones-and run a pilot study of the questionnaires, so as to be given the chance to make any alterations emerged as necessary.

After proceeding with any changes in the questionnaires based on the pilot study, the main research took place and the researcher entered the classrooms herself explaining the purpose of the study to the students willing to participate in it. The participants were given a time-span of ten (10') minutes to fill in the questionnaires. Any questions raised were answered by the researcher and, as a 
whole, the procedure was carried out as expected. The completion of the questionnaires was followed by the statistical analysis of the data as follows.

\subsection{Statistical Analysis}

Based on the purpose and the hypotheses of the study, univariate and multivariate statistical analyses were conducted to address the purposes of the present study. In order to examine the differences among the participants in the study based on their gender, nationality, school grade, and area of their school, a series of multivariate analysis of variance (MANOVA) were conducted. Follow-up univariate ANOVAs were performed on the subscales of significant MANOVA effects (Scheffe test). In addition, Bonferroni adjustment was applied to control for the inflation of Type I error (Tabachnick \& Fidell, 2006).

\section{Results}

\subsection{Descriptive Statistics}

As far as the social-family factors are concerned, the results indicate that students are highly encouraged by their families to follow the profession they wish $(M=4.31, S D=0.90)$, with a high percentage of them agreeing $(32.7 \%)$ or strongly agreeing $(52.3 \%)$ on the aforementioned issue, reaching a total rate of $85 \%$. Moreover, students' answers, regarding the amount of encouragement they receive by their parents to do their best, reached a high percentage, by agreeing at a percentage of $20.8 \%$ and totally agreeing at a percentage of $73.3 \%$. On the other hand, based on the students' answers, it seems that they are helped with their schoolwork by their families less $(M=3.23, S D=1.19)$, and they are supported in the occasion of low grades in a similar way $(M=3.35, S D=1.125)$. Further, parents are more than aware of the friends and acquaintances their children have, showing a high percentage on that $(M=4.07, S D=1.02)$. Finally, judging from the answers of the students of our sample, the members of their families visit schools quite often, so as to be informed by their children's teachers about their academic progress $(M=3.86, S D=1.06)$ (Figure 1).

\subsection{Differences among the Groups}

The differences in the social-family factors based on the examined independent factors (gender, nationality, school area, school grade, number of friends) are presented in Tables 1-5. In more detail, multiple analysis of variance was applied to examine the differences among the independent variables, as well as, the means $(M)$, the standard deviations $(S D)$, the statistical significance indices [Wilk's $\Lambda, F$-value, degrees of freedom ( $d f$ ), statistical significance level (p-value) and effect size $\left.\left(\eta_{p}^{2}\right)\right]$.

The means $(M)$ and standard deviations $(S D)$ of the social-family factors in boys and girls are presented in Table 1. Multivariate analysis of variance (MANOVA) results indicated significant differences between boys and girls in the social-family factors (Wilks' $\Lambda=.982, F_{1,1508}=4.488, p<.001, \eta_{p}^{2}=.02$ ). Fol- 
low-up analysis in each dependent factor, applying Bonferroni adjustment, indicated significant differences in the following factors: 1) parental professional encouragement $\left.\left(F_{1,1508}=7.424, p<.01, \eta_{p}^{2}=.01\right), 2\right)$ parental knowledge about

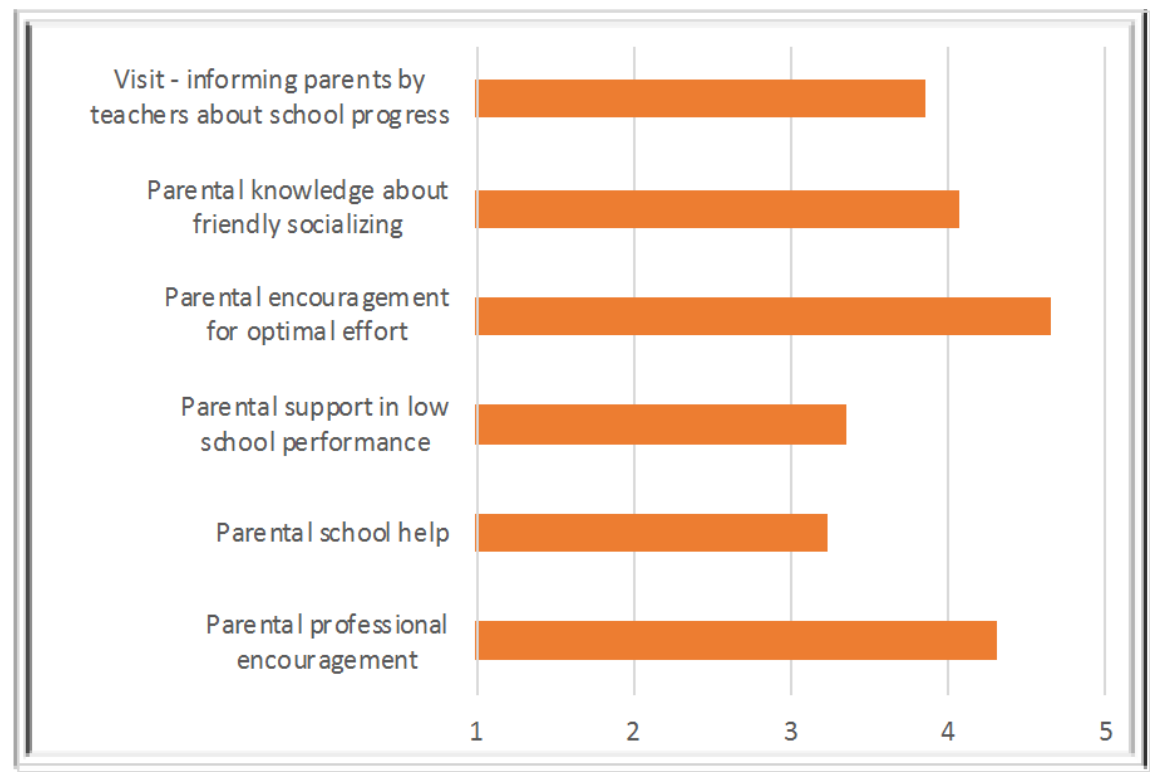

Figure 1. Social-family factors.

Table 1. Means $(M)$ and standard deviations $(S D)$ of the social-family factors in boys and girls in the total sample.

\begin{tabular}{lcc}
\hline \multicolumn{1}{c}{ Social/Family Factors } & Boys & Girls \\
\cline { 2 - 3 } & $M(S D)$ & $M(S D)$ \\
\hline Parental professional encouragement & $4.25(0.92)$ & $4.38(0.85)$ \\
Parental school help & $3.21(1.20)$ & $3.25(1.17)$ \\
Parental support in low school performance & $3.34(1.25)$ & $3.37(1.26)$ \\
Parental encouragement for optimal effort & $4.61(0.73)$ & $4.68(0.68)$ \\
Parental knowledge about friendly socializing & $3.98(1.05)$ & $4.18(0.97)$ \\
Visit-parents' informing by teachers about school progress & $3.76(1.09)$ & $3.96(1.00)$ \\
\hline
\end{tabular}

Table 2. Means $(M)$ and standard deviations $(S D)$ of the social-family factors of the indigenous and foreign students in the total sample.

\begin{tabular}{|c|c|c|}
\hline \multirow{2}{*}{ Social/Family Factors } & \multicolumn{2}{|c|}{ Indigenous students Foreign students } \\
\hline & $M(S D)$ & $M(S D)$ \\
\hline Parental professional encouragement & $4.34(0.86)$ & $4.07(1.10)$ \\
\hline Parental school help & $3.27(1.18)$ & $2.88(1.22)$ \\
\hline Parental support in low school performance & $3.38(1.25)$ & $3.12(1.28)$ \\
\hline Parental encouragement for optimal effort & $4.66(0.68)$ & $4.52(0.91)$ \\
\hline Parental knowledge about friendly socializing & $4.08(1.01)$ & $4.00(1.05)$ \\
\hline Visit-parents' informing by teachers about school progress & $3.90(1.04)$ & $3.53(1.11)$ \\
\hline
\end{tabular}


Table 3. Means $(M)$ and standard deviations $(S D)$ of the social-family factors of the $1^{\text {st }}$, $2^{\text {nd }}$, and $3^{\text {rd }}$ Grade Junior High School students in the total sample.

\begin{tabular}{lccc}
\hline \multirow{2}{*}{\multicolumn{1}{c}{ Social/Family Factors }} & $\begin{array}{c}1^{\text {st }} \text { Grade High } \\
\text { School }\end{array}$ & $\begin{array}{c}2^{\text {nd }} \text { Grade High } \\
\text { School }\end{array}$ & $\begin{array}{c}3^{\text {rd }} \text { Grade High } \\
\text { School }\end{array}$ \\
\cline { 2 - 4 } & $M(S D)$ & $M(S D)$ & $M(S D)$ \\
\hline Parental professional encouragement & $4.26(0.92)$ & $4.35(0.86)$ & $4.33(0.88)$ \\
Parental school help & $3.34(1.15)$ & $3.24(1.22)$ & $3.09(1.20)$ \\
Parental support in low school performance & $3.38(1.26)$ & $3.33(1.31)$ & $3.33(1.19)$ \\
Parental encouragement for optimal effort & $4.66(0.70)$ & $4.62(0.68)$ & $4.63(0.74)$ \\
Parental knowledge about friendly socializing & $4.05(1.07)$ & $4.04(0.98)$ & $4.13(0.96)$ \\
Visit-parents' informing by teachers about & $3.94(1.00)$ & $3.85(1.07)$ & $3.77(1.09)$ \\
school progress & & & \\
\hline
\end{tabular}

Table 4. Means $(M)$ and standard deviations $(S D)$ of the social-family factors of the urban, semi-urban, and rural school students in the total sample.

\begin{tabular}{lccc}
\hline \multirow{2}{*}{\multicolumn{1}{c}{ Social/Family Factors }} & Urban area & Semi-circular area & Rural area \\
\cline { 2 - 4 } & $M(S D)$ & $M(S D)$ & $M(S D)$ \\
\hline Parental professional encouragement & $4.31(0.87)$ & $4.16(1.07)$ & $4.35(0.92)$ \\
Parental school help & $3.32(1.15)$ & $3.32(1.14)$ & $2.86(1.29)$ \\
Parental support in low school performance & $3.30(1.26)$ & $3.62(1.13)$ & $3.49(1.23)$ \\
Parental encouragement for optimal effort & $4.65(0.70)$ & $4.57(0.68)$ & $4.64(0.71)$ \\
Parental knowledge about friendly socializing & $4.06(1.01)$ & $4.26(0.77)$ & $4.08(1.09)$ \\
Visit-parents' informing by teachers about & $3.85(1.04)$ & $3.90(1.02)$ & $3.90(1.10)$ \\
school progress & & & \\
\hline
\end{tabular}

Table 5. Means $(M)$ and standard deviations $(S D)$ of the social-family factors of the students with different number of friends in the total sample.

\begin{tabular}{lcccc}
\hline \multicolumn{1}{c}{ Social/Family Factors } & $\begin{array}{c}\text { Friends } \\
\text { absence }\end{array}$ & Few friends & $\begin{array}{l}\text { Several } \\
\text { friends }\end{array}$ & Many friends \\
\cline { 2 - 5 } & $M(S D)$ & $M(S D)$ & $M(S D)$ & $M(S D)$ \\
\hline Parental professional encouragement & $4.17(1.27)$ & $4.31(0.85)$ & $4.28(0.90)$ & $4.33(0.89)$ \\
Parental school help & $2.33(1.09)$ & $3.16(1.27)$ & $3.26(1.14)$ & $3.28(1.17)$ \\
Parental support in low school performance & $2.54(1.35)$ & $3.28(1.27)$ & $3.41(1.20)$ & $3.38(1.26)$ \\
Parental encouragement for optimal effort & $4.08(1.28)$ & $4.59(0.80)$ & $4.67(0.65)$ & $4.67(0.66)$ \\
Parental knowledge about friendly socializing & $3.54(1.38)$ & $4.17(1.03)$ & $4.12(0.95)$ & $4.03(1.02)$ \\
$\begin{array}{l}\text { Visit-parents' informing by teachers about } \\
\text { school progress }\end{array}$ & $2.87(1.34)$ & $3.90(1.04)$ & $4.12(0.95)$ & $4.03(1.02)$ \\
\hline
\end{tabular}

friendly socializing $\left(F_{1,1508}=14.810, p<.001, \eta_{p}^{2}=.01\right)$, and 3) Visit-parents' informing by teachers about school progress $\left(F_{1,1508}=13.603, p<.001, \eta_{p}^{2}=.01\right)$. More specifically, girls indicated significant higher mean values compared to boys in the three aforementioned factors indicating a greater degree of agree- 
ment as to the existence of the specific behavior by their parents and family (Figure 2).

The means $(M)$ and standard deviations $(S D)$ of the social-family factors in the indigenous and foreign students are presented in Table 2. Multivariate analysis of variance (MANOVA) results indicated significant differences between indigenous and foreign students in the social-family factors (Wilks' $\Lambda=.976$, $\left.F_{1,1508}=6.086, p<.001, \eta_{p}^{2}=.02\right)$. Follow-up analysis in each dependent factor, applying Bonferroni adjustment, indicated significant differences in the following factors: 1) parental professional encouragement $\left(F_{1,1508}=13.488, p<.001, \eta_{p}^{2}\right.$ $=.01), 2)$ parental school help $\left.\left(F_{1,1508}=16.463, p<.001, \eta_{p}^{2}=.01\right), 3\right)$ parental support in low school performance $\left.\left(F_{1,1508}=6.483, p<.01, \eta_{p}^{2}=.01\right), 4\right)$ parental encouragement for optimal effort $\left(F_{1,1508}=5.628, p<.05, \eta_{p}^{2}=.01\right)$, and 5) visit parents' informing by teachers about school progress $\left(F_{1,1508}=18.397, p<.001, \eta_{p}^{2}\right.$ $=.01$ ). In more detail, indigenous students indicated significant higher mean values compared to foreign students in the five aforementioned factors indicating a greater degree of agreement as to the existence of the specific behavior by their parents and family (Figure 3 ).

The means $(M)$ and standard deviations $(S D)$ of the social-family factors in the indigenous and foreign students are presented in Table 3. Multivariate analysis of variance (MANOVA) results indicated significant differences among the $1^{\text {st }}, 2^{\text {nd }}$, and $3^{\text {rd }}$ Grade Junior High School students in the total sample (Wilks' $\Lambda$ $=.983, F_{2,1507}=2.174, p<.01, \eta_{p}^{2}=.01$ ). Follow-up ANOVAs (Tukey test) on each dependent factor, applying Bonferroni adjustment, indicated significant differences in the following factors: 1$)$ parental school help $\left(F_{2,1507}=5.653, p\right.$ $\left.<.01, \eta_{p}^{2}=.01\right)$ and 2) visit - parents' informing by teachers about school progress $\left(F_{2,1507}=3.093, p<.05, \eta_{p}^{2}=.01\right)$. In more detail, $1^{\text {st }}$ Grade Junior High

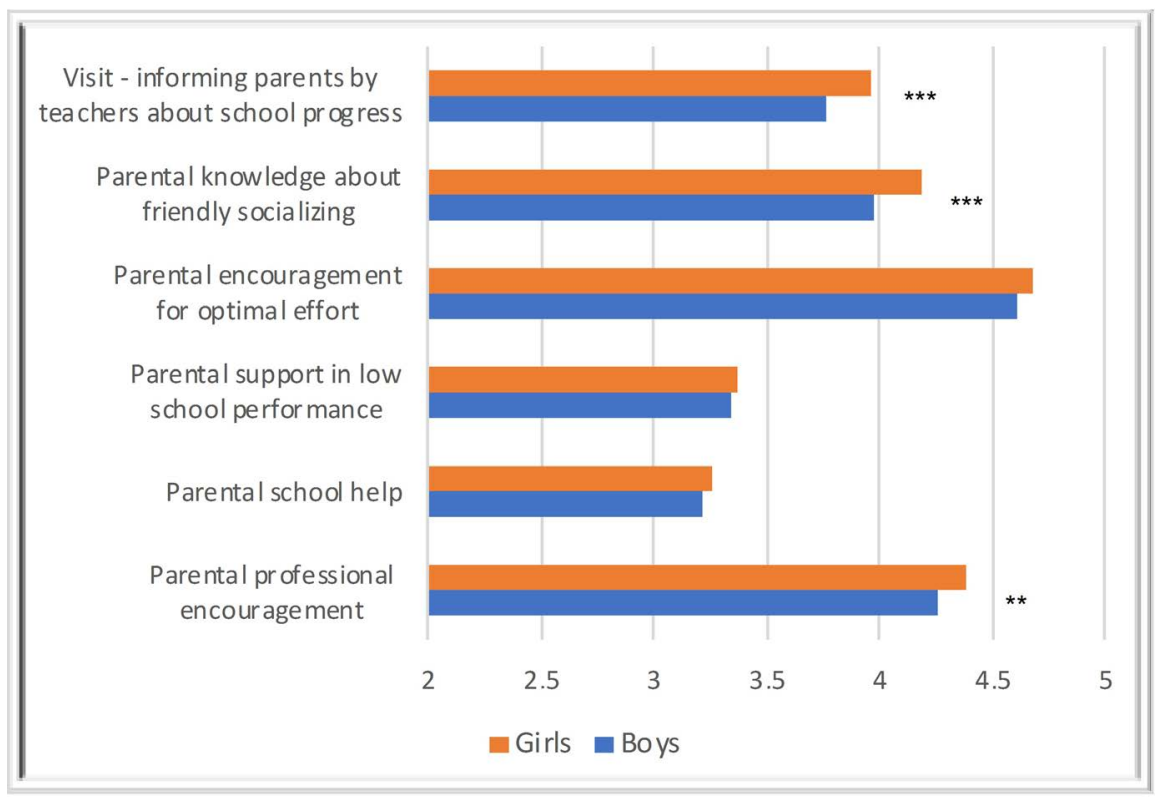

Figure 2. Histogram of students' responses (boys-girls) in the social-family factors. 


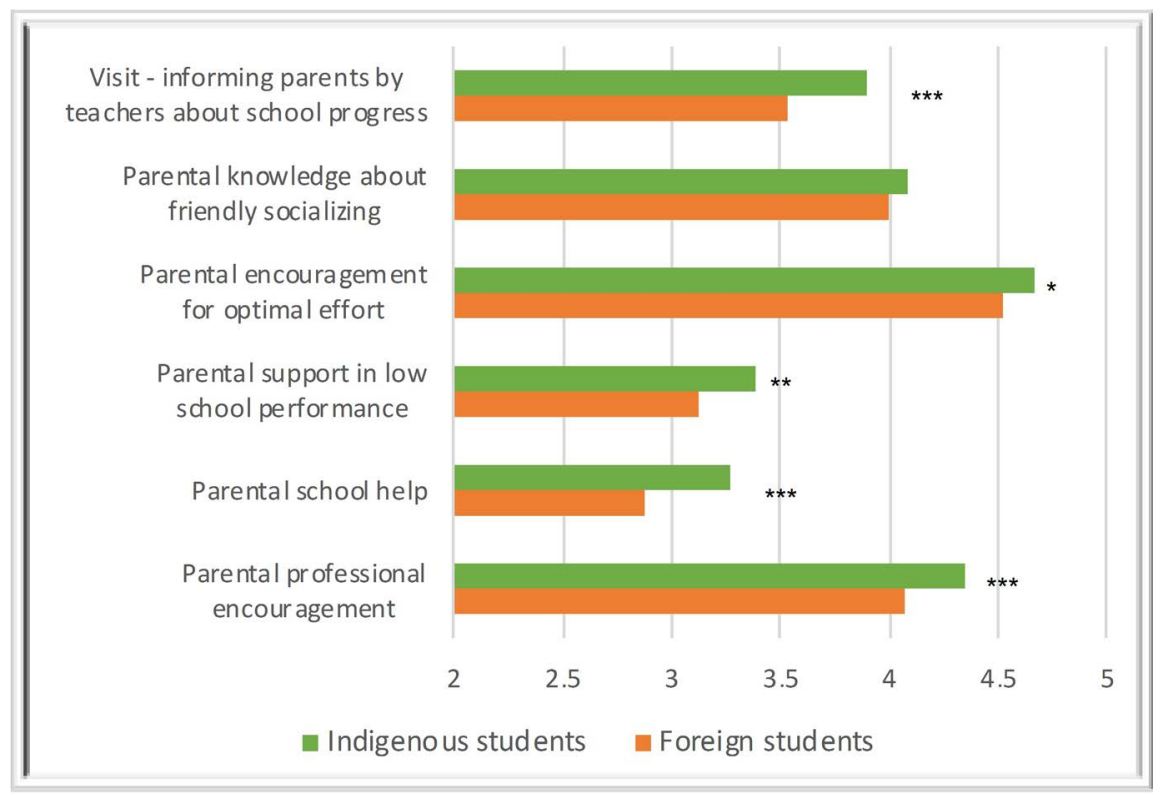

Figure 3. Histogram of students' responses (nationality) in the social-family factors.

School students revealed significant higher mean values compared to students attending the other two grades of Junior High School, and mainly compared to the $3^{\text {rd }}$ Grade Junior High School students.

The means $(M)$ and standard deviations $(S D)$ of the social-family factors of the urban, semi-urban, and rural school students in the total sample are presented in Table 4. Multivariate analysis of variance (MANOVA) results indicated significant differences among the urban, semi-urban, and rural school students in the total sample (Wilks' $\Lambda=.959, F_{2,1507}=5.275, p<.001, \eta_{p}^{2}=.02$ ). Follow-up ANOVAs (Tukey test) on each dependent factor, applying Bonferroni adjustment, indicated significant differences in the following factors: 1) parental school help $\left(F_{2,1507}=18.257, p<.001, \eta_{p}^{2}=.02\right)$, and 2$)$ parental support in low school performance $\left(F_{2,1507}=4.147, p<.05, \eta_{p}^{2}=.01\right)$. In more detail, the urban and semi-urban area students revealed significant higher mean values compared to the rural students in the parental school help, whereas the urban and semi-urban area students revealed significant lower mean values compared to the rural students regarding parental support in low school performance.

The means $(M)$ and standard deviations $(S D)$ of the social-family factors of students with a different number of friends (not any, few, several, many friends) are presented in Table 5. Multivariate analysis of variance (MANOVA) results indicated significant differences among the students with a different number of friends (Wilks' $\Lambda=.961, F_{3,1506}=3.331, p<.001, \eta_{p}^{2}=.01$ ). Follow-up ANOVAs (Tukey test) on each dependent factor, applying Bonferroni adjustment, indicated significant differences in the following factors: 1) parental school help $\left.\left(F_{3,1506}=5.464, p<.001, \eta_{p}^{2}=.01\right), 2\right)$ parental support in low school performance $\left.\left(F_{3,1506}=4.167, p<.01, \eta_{p}^{2}=.01\right), 3\right)$ parental encouragement for optimal effort $\left.\left(F_{3,1506}=6.205, p<.001, \eta_{p}^{2}=.01\right), 4\right)$ parental knowledge about friendly 
socializing $\left(F_{3,1506}=3.859, p<.01, \eta_{p}^{2}=.01\right)$, and 5) visit - parents' informing by teachers about school progress $\left(F_{3,1506}=7.478, p<.001, \eta_{p}^{2}=.02\right)$. In more detail, in the five aforementioned issues raised, the students with no friends at all indicated significant lower mean values compared to the rest of the students, no matter what their number of friends is (Figure 4).

\section{Discussion}

The purpose of the present study was to outline a range of family factors which can potentially influence dropping out of school. It supports the fact that dropping out of school can rarely be put down to one event or one impact, but rather it is influenced by a range of interacting factors, which are specific to the individual contexts of each child. To this end, early school leaving is seen as a process rather than an event, with individual cases being difficult to replicate. Yet, through literature, patterns emerge which suggest that, in particular contexts, certain children are more prone to dropping out than others and specific measures taken might address some of the risks these children face.

In this vein, the main purpose of the current research was to examine those family factors that place Greek young people at risk of leaving school early. The relevant literature has revealed that those at most risk of dropping out of school are children from socially disadvantaged family environments (Steinberg, Dornbusch, \& Brown, 1992; Banks, 2006; Gandara \& Contreras, 2009; Neuman \& Dickinson, 2000; Rumberger, 2011; Farrington, Roderick, Allensworth, Ngaoka, Keyes, Johnson, \& Beechum, 2012; Bloom \& Unterman, 2014).

Followingly, the differences in the social-family factors based on the examined factors of gender, nationality, school area, grade of attendance and number of friends are analyzed in this study, which has identified six "at risk" indicators

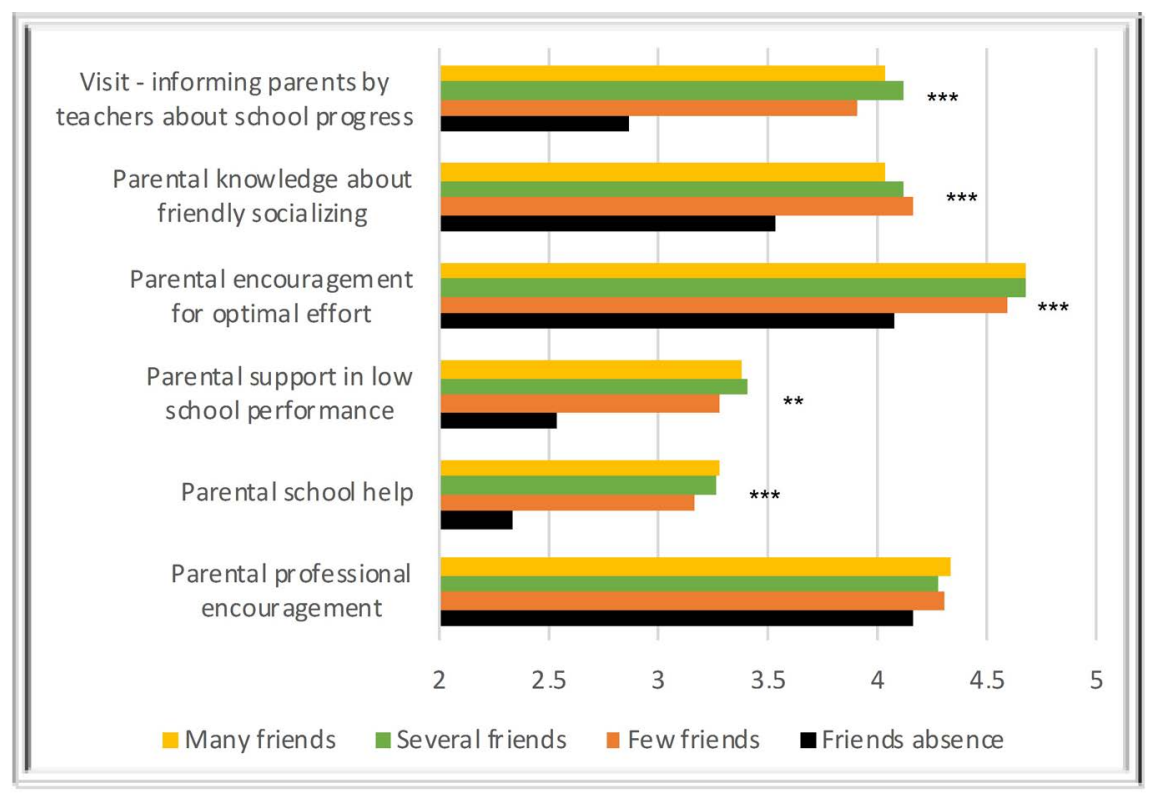

Figure 4. Histogram of students responses (different number of friends) in the social-family factors. 
from the literature: parental professional encouragement, parental school help, parental support in low school performance, parental encouragement for optimal effort, parental knowledge of children's social life and the frequency of parents' visits to school and their relevant informing by teachers.

The descriptive analysis showed that although the participants in the study are highly encouraged by their families to follow the profession they wish and do their best so as to achieve their academic goals, they are not adequately helped by them with their schoolwork and are not supported in the event of low grading, which, according to various researchers (Tansel, 2002; Cardoso \& Verner, 2007; Braun \& Clarke, 2013) are considered to be variables of pivotal importance to children's social and academic progress.

More specifically, examining the aforementioned independent factors, significant differences have been aroused. Thus, regarding parental professional encouragement, parental knowledge of children's social life and the frequency of parents' visits to school and their relevant informing by teachers, girls indicated significant higher mean values compared to boys. This finding is compatible with the findings of various researchers (Coley, 2001; Crowder \& South, 2003; Davis \& Bauman, 2008; Rumberger, 2011), according to which, girls are more supported by their family environments to go along with their studies, to achieve higher goals in their academic course and, in general, they seem to have better school performance than boys (Coley, 2001). Gender stereotypes and differences that used to hold girls back and prepare them only for the role of a wife and a mother no longer exist (UNICEF, 2014; Subrahmanyam, 2016). Further, girls appear to be the recipients not only of more educational resources than boys but of more moral support and encouragement by their families (Furlong, 1986; Weiner, 1986; King, 1987; Acker, 1988; Argyle, 2002; West \& Pennell, 2003; Davis \& Bauman, 2008; Ryle, 2011). Additionally, the thorough study of the research findings has brought us to the conclusion that the high family support is positively linked to a positive attitude towards the successful completion of school (Johnson \& Johnson, 1983; Johnson, Johnson, \& Anderson, 1983; Johnson, Johnson, Buckman, \& Richards, 1985; Johnson, Johnson, \& Holubec, 1994). However, according to the findings under scrutiny, it is claimed that this sense of achievement is differently perceived by families concerning the distinction between boys and girls. Parents should be aware of such a fact, as it is also mentioned in similar studies (Johnson \& Johnson, 1999; Garton \& Pratt, 2001; Fawcett \& Garton, 2005).

Furthermore, as far as the nationality of the participants in our study is concerned, significant differences are revealed between students that are of Greek origin and those coming from other countries. In more detail, indigenous students indicated significant higher mean values compared to foreign students in the five aforementioned variables indicating a greater degree of agreement as to the existence of the specific behavior by their parents and family in general. It is widely supported in literature that foreign students tend to fail in school more than native ones and their dropping out rates are higher (Ogbu, 1987; Banks, 
2006; Rumberger, 2011; Bloom \& Unterman, 2014). The reasons that usually differentiate the nationally, linguistically and culturally different students are various. Namely, it is claimed that their families' cultural differentiation, socio-economic and educational background are prevailing factors of school failure and ultimately, dropping out of school (Edwards, 1998; Banks, 2006; Farrington, Roderick, Allensworth, Ngaoka, Keyes, Johnson, \& Beechum, 2012). Additionally, parental support and encouragement for the completion of studies is reported to be less in foreign families, a fact that is confirmed in the present study. This could be explained by the fact that foreign students' parents are not in a position to offer their children help with their schoolwork or initiate a parent-teacher relationship so as to be constantly informed about their children's progress at school, as they are not native speakers of the language spoken and taught at schools. Finally, since there are the aforementioned barriers of culture, language, attitude and expectations on the part of foreign students, they tend to be more prone to absenteeism, truancy and juvenile delinquency-all reported as factors of dropping out of school (Steinberg, Dornbusch, \& Brown, 1992; Ou, Mersky, Reynolds, \& Kohler, 2007; Finn, Fish, \& Scott, 2008; Gandara \& Contreras, 2009; Glesmann, Krisberg, \& Marchionna, 2010; Rumberger, 2011; Bloom \& Unterman, 2014), with parents showing less or no interest in getting to know their children's social life, an important finding of our study.

Another significant finding of the present study is the emergence of differences among the three grades of Junior High School attended by the participants in the research. In particular, the $1^{\text {st }}$ Grade Junior High School students revealed significant higher mean values regarding the variables of the questionnaire administered, compared to the students who attend the other two Junior High School grades, and mainly compared to the $3^{\text {rd }}$ Grade High School students. This finding is compatible with the general consensus researchers have reached (Viadero, 2001; Allaire, Michaud, Boissonneault, Cote, \& Diallo, 2005; Coyle, 2009; Ratelle, Guay, Vallerand, Larose, \& Senecal, 2007; Zimmerman, 2008; Rumberger \& Lim, 2008; Rumberger, 2011; Frankenberg \& Kotok, 2013; Bloom \& Unterman, 2014; Subrahmanyam, 2016), according to which the highest dropping out rates are reported to appear before the completion of the compulsory school cycle, which, generally speaking, is Junior High school, as is the case with the Greek educational system. The specific findings could be explained by the fact that the sense of belonging is higher in students of the first grade of Junior High school, as the bonds that have been created with school as an institution in Primary school are stronger and students' motivation is greater (Rotermund, 2010 in Rumberger, 2011, p. 187). Moreover, parents seem to support and guide children more at a younger age, due to their emotional state as young children, than at a later stage of their studies. Also, students' social life changes as children turn into teenagers, initiating, thus, a different emotional state (Ensminger \& Slusarcick, 1992; Garnier, Stein, \& Jacobs, 1997; Battin-Pearson, 2000; Reynolds, Ou, \& Topitzes, 2004; Pomerantz, Moorman, \& Litwack, 2007). The fact that the students feel that they do not receive adequate family and academic support re- 
veals that they have a different perception of the school climate prevailing Primary and Junior High school. Such a differentiation is emphasized by the fact that Primary school students feel less alienated and experience feelings of extrinsic motivation, family support and academic self-esteem, compared to Junior High school students. The specific outcomes are congruent with those of the international literature (Samaha \& DeLisi, 2000; Underwood, Underwood, \& Wood, 2000; Druyan, 2001).

Additionally, as far as the places where the schools our study was conducted in were located, the urban and semi-urban area students revealed significant higher mean values compared to the rural students in the parental school help variable, whereas the urban and semi-urban area students revealed significant lower mean values compared to the rural students regarding parental support in low school performance. The particular fact is actually compatible with the findings of several studies (Goleman, 1995; Lempers \& Clark, 1998; Lester \& Miller, 1990; Singh \& Sinha, 2002), in which it is undisputable that children's ability to successfully recognize and manage the importance of school completion, to develop friendly relationships, to be able to work in groups, to seek for techniques in order to resolve conflicts among the members of the school community, and to really understand themselves and their behaviour, flourish in family environments located in urban areas, with the aid of supportive and emotionally mature parents. Relevant studies (Tomlinson, 1991; Comer, Haynes, Joyner, \& Ben-Arie, 1996; Christenson \& Sheridan, 2001; Epstein, 2001) reveal that children, whose parents are indifferent and unconcerned, end up being impulsive, with less emotional self-control and unable to form any kind of relationship-factors that are stated as indicative of early school leaving, while those, whose parents are caring, devoting a lot of their time to them, seem to be generally more sociable, adaptable, self-conscious and academically successful. Therefore, it is supported that these social and emotional skills are acquired, cultivated and brought to perfection in such a family environment that is not malfunctioning and where healthy patterns of behaviour are projected by adults with high aspirations for their children's fruitful academic course (Fraser \& Walberg, 1991; Pianta, 1999; Matsagouras \& Voulgaris, 2006).

In an effort to interpret and comment on the specific findings, it seems that the parents of the students in urban and semi-urban areas, who participated in the present study, are of a high social and economic status, trying to provide them with as much as they can possibly offer, while parents living in rural areas are more absorbed in their daily efforts to make a living and probably get so carried away by this endeavor that they probably neglect issues of paramount importance to their children's upbringing, thus resulting in their deprivation of a full emotional and educational development.

Finally, another important finding of the present study is that the female participants of our sample who stated that they had very few or no friends at all showed significant higher mean values compared to the rest of the students (no matter how many friends they reported), a fact that is totally compatible with the 
findings of other researchers (Nunan, 1987; Mitchell, 1988; Lawrence, 1990; Lamb, 1995; Huffman \& Speer, 2000; Farrington, Roderick, Allensworth, Ngaoka, Keyes, Johnson, \& Beechum, 2012; Thapa, Cohen, Guffey, \& Higgins-D'Alessandro, 2013). Reading between the lines, it can be inferred that students are not only supported academically on school subjects by their families, but on personal matters as well, a fact that gives ground to the development of friendlier, more effective and personal relationships among students and, ultimately, create a more positive school climate, which is considered to act as a deterrent from dropping out of school (Zullig, Koopman, Patton, \& Ubbes, 2010; Simba, Agak, \& Kabuka, 2016; Kotok, Ikoma, \& Bodovski, 2016).

\section{Conclusion}

Having concluded, within the limitations of the present study, it is hoped that not only the characteristics of the students at risk of dropping out of school have gained distinction, but also the significance of parental involvement in their children's education and upbringing in general, as well as the awareness of their indispensable role in the improvement of this educational process have been highlighted. Parents' personal educational, economic, social and cultural background, their own educational aspirations, the ambitions, values and hopes they pass on to their children, their support and encouragement in every step their children take are all key determinants of these children's successful academic course and school completion.

"For most children to succeed in school, their parents' interest in their learning is of paramount importance. But this interest ought to be with what happens on a daily basis, because this is how the child lives, and this is how he understands his life. The essential ingredient in most children's success in school is a positive relation to his parents" (Bettelheim, 1987: p. 69, cited in Kainuwa \& Yusuf, 2019)

\section{Conflicts of Interest}

The authors declare no conflicts of interest regarding the publication of this paper.

\section{References}

Acker, S. (1988). Teachers, Gender and Resistance. British Journal of Sociology of Education, 9, 307-322. https://doi.org/10.1080/0142569880090304

Alexander, K. L., Entwisle, D. R., \& Horsey, C. S. (1997). From First Grade Forward: Early Foundations of High School Dropout. Sociology of Education, 70, 87-107. https://doi.org/10.2307/2673158

Allaire, G., Michaud, J., Boissonneault, J., Cote, D., \& Diallo, P. (2005). Le decrochage au secondaire en Ontario francais: Le point de vue des Jeunes. Sudbury: Institut Franco-Ontarien, Universite Laurentienne.

Argyle, M. (2002). The Psychology of Happiness. New York: Routledge.

Arum, R., \& Velez, M. (2012). Improving Learning Environments in Schools: School Dis- 
cipline and Student Achievement in Comparative Perspective. Palo Alto, CA: Stanford University Press. https://doi.org/10.11126/stanford/9780804778039.001.0001

Astone, N. M., \& McLanahan, S. S. (1991). Family Structure, Parental Practices and High School Completion. American Sociological Review, 56, 309-320. https://doi.org/10.2307/2096106

Babalis, Th. (2011). Children of Single-Parent Families: Helping Their School Adjustment. Athens: Diadrassi.

Babalis, Th., \& Tsoli, K. (2017). Classroom Life: Shaping the Learning Environment, Classroom Management, Strategies and Teaching Techniques. New York: Nova Publishers.

Babalis, Th., Tsoli, K., Nikolopoulos, V., \& Maniatis, P. (2014). The Effect of Divorce on School Performance and Behavior in Preschool Children in Greece: An Empirical Study of Teachers' Views. Psychology, 5, 20-26. https://doi.org/10.4236/psych.2014.51005

Babalis, Th., Xanthacou, Y., \& Kaila, M. (Eds.) (2018). Single-Parenting in the 21st Century: Perceptions, Issues and Implications. New York: Nova Publishers

Baldwin, R. (2000). Theories of Child Development. New York: Wiley and Sons.

Ball, J. S., Davies, J., David, M., \& Reay, D. (2002). Classification and Judgement: Social Class and the "Cognitive Structures" of Choice of Higher Education. British Journal of Sociology of Education, 23, 343-456. https://doi.org/10.1080/01425690120102854

Banks, J. A. (2006). Imperatives in Ethnic Minority Education. In J. A. Banks (Ed.), Race, Culture, and Education: The Selected Works of James A. Banks. New York: Routledge. https://doi.org/10.4324/9780203088586

Battin-Pearson, S. (2000). Predictors of Early School Dropout: A Test of Five Theories. Journal of Educational Psychology, 92, 568-582. https://doi.org/10.1037/0022-0663.92.3.568

Bettelheim, B. (1987). A Good Enough Parent: A Book on Child Rearing. New York: Alfred A. Knoff Inc.

Bjorklund, A., \& Salvanes, K. (2010). Education and Family Background. IZA Discussion Paper 5002.

Bloom, H. S., \& Unterman, R. (2014). Can Small High Schools of Choice Improve Educational Prospects for Disadvantaged Students? Journal of Policy Analysis and Management, 33, 290-319. https://doi.org/10.1002/pam.21748

Bohon, C., Garber, J., \& Horowitz, J. L. (2007). Predicting School Dropout and Adolescent Sexual Behavior in Offspring of Depressed and Nondepressed Mothers. Journal of the American Academy of Child \& Adolescent Psychiatry, 46, 15-24.

https://doi.org/10.1097/01.chi.0000246052.30426.6e

Braun, V., \& Clarke, V. (2013). Successful Qualitative Research: A Practical Guide for Beginners. London: Sage.

Bruneforth, M. (2006). Characteristics of Children Who Drop Out of School and Comments on the Drop-Out Population Compared to the Population of Out-of-School Children. Background paper for the EFA Global Monitoring Report 2007. https://unesdoc.unesco.org/images/0014/00147794e.pdf

Bynner, J., \& Joshi, H. (2002). Equality and Opportunity in Education: Evidence from the 1958 and 1970 Birth Cohort Studies. Oxford Review of Education, 28, 405-425. https://doi.org/10.1080/0305498022000013599

Cardoso, A. R., \& Verner, D. (2007). School Dropout and Push-Out Factors in Brazil: The 
Role of Early Parenthood, Child Labour, and Poverty. IZA Discussion Paper No. 2515, Bonn: Institute for the study of Labour. Washington DC. http://ftp.iza.org/dp2515.pdf

Chapman, K. (1986). The Sociology of Schools. New York: Tavistock Publications.

Chavkin, N. F. (1993). Families and Schools in a Pluralistic Society. Albany, NY: SUNY Press.

Chenge, R. P., Chenge, E., \& Maunganidze, L. (2017). Family Factors That Contribute to School Dropout in Rushinga District in Zimbabwe. International Journal of Law, Humanities \& Social Science, 1, 87-105.

Chenge, R. P., Chenge, E., \& Maunganidze, L. (2017). Family Factors That Contribute to School Dropout in Rushinga District in Zimbabwe. International Journal of Law, Humanities \& Social Science, 1, 87-105.

Chevalier, A., Halmon, C., O'Sullivan, V., \& Walker, I. (2005). The Impact of Parental Income and Education on the Schooling of their Children. Lancaster University Management School Working Paper 2010/36.

Child, J. (1972). Organizational Structure, Environment and Performance: The Role of Strategic Choice. Sociology, 6, 1-22. https://doi.org/10.1177/003803857200600101

Christenson, S. L. D., \& Sheridan, S. M. (2001). Schools and Families: Creating Essential Connections for Learning. New York: The Guilford Press.

Christenson, S. L., \& Conoley, J. C. (1992). Home-School Collaboration: Enhancing Children's Academic and Social Competence. Silver Spring, MD: National Association of School Psychologists.

Christenson, S. L., Rounds, T., \& Gorney, D. (1992). Family Factors and Student Achievement: An Avenue to Increase Students' Success. School Psychology Quarterly, 7, 178-206. https://doi.org/10.1037/h0088259

Chugh, S. (2011). Dropout in Secondary Education. New Delhi: National University of Educational Planning and Administration.

Coelho, E. (1998). Teaching and Learning in Multicultural Schools. An Integrated Approach. Clevedon-Philadelphia: Multilingual Matters Ltd.

Coleman, J. S. (1988). Social Capital in the Creation of Human Capital. American Journal of Sociology, 94, 95-120. https://doi.org/10.1086/228943

Coley, R. (2001). Differences in the Gender Gap: Comparisons across Racial/Ethnic Groups in Education and Work. Princeton, NJ: Educational Testing Service.

Comer, J. P., Haynes, N. M., Joyner, E. T., \& Ben-Arie, M. (1996). Rallying the Whole Village: The Comer Process for Reforming Education. New York: Teachers College Press.

Corson, D. (1998). Changing Education for Diversity. Buckingham-Philadelphia: Open University Press.

Coyle, D. (2009). The Talent Code. New York: Bantam.

Croninger, R. G., \& Lee, V. L. (2001). Social Capital and Dropping Out of High School: Benefits to At-Risk Students of Teachers' Support and Guidance. Teachers College Record, 103, 548-581. https://doi.org/10.1111/0161-4681.00127

Crowder, K., \& South, S. J. (2003). Neighborhood Distress and School Dropout: The Variable Significance of Community Context. Social Science Research, 32, 659-698. https://doi.org/10.1016/S0049-089X(03)00035-8

D’Agostino, J. (2000). Instructional and School Effects on Students' Longitudinal Reading and Mathematics Achievements. School Effectiveness and School Improvement, 11, 
197-235. https://doi.org/10.1076/0924-3453(200006)11:2;1-Q;FT197

Dalton, B., Glennie, E., \& Ingels, S. J. (2009). Late High School Dropouts: Characteristics, Experiences, and Changes across Cohorts (NCES 2009-307). Washington DC: National Center for Education Statistics, U.S. Department of Education. http://nces.ed.gov/Pubsearch/Pubsinfo.Asp?Pubid=2009307

Davies, L., \& Geoff, W. (1983). Review Symposium. British Journal of Sociology of Education, 4, 255-262. https://doi.org/10.1080/0142569830040304

Davis, J. W., \& Bauman, K. J. (2008). School Enrollment in the United States: 2006. Washington DC: Census Bureau, U.S. Department of Commerce.

Day, J. C. (1993). Population Projections of the United States, by Age, Sex, Race, and Hispanic Origin: 1993 to 2050. Washington DC: U.S. Government Printing Office.

Delpit, D. L. (1988). The Silenced Dialogue: Power and Pedagogy in Educating Other People's Children. Harvard Educational Review, 58, 129-146. https://doi.org/10.17763/haer.58.3.c43481778r528qw4

Demaine, J. (1989). Race, Categorization and Educational Achievement. British Journal of Sociology of Education, 10, 195-214. https://doi.org/10.1080/0142569890100205

Deslandes, R., Potvin, P., \& Leclerc, D. (1999). Family Characteristics as Predictors of School Achievement: Parental Involvement as a Mediator. Journal of Education, 34, 135-153.

Druyan, S. (2001). A Comparison of Four Types of Cognitive Conflict and Their Effect on Cognitive Development. International Journal of Behavioural Development, 25, 226-236. https://doi.org/10.1080/01650250042000276

Edwards, V. (1998). The Power of Babel-Teaching and Learning in Multilingual Classrooms. Staffordshire: Trentham Books Limited.

Ensminger, M. E., \& Slusarcick, A. L. (1992). Paths to High School Graduation or Dropout: A Longitudinal Study of a First-Grade Cohort. Sociology of Education, 65, 95-113. https://doi.org/10.2307/2112677

Epstein, J. (2001). School, Family and Community Partnerships. Preparing Educators and Improving Schools. Boulder, CO: Westview Press.

Fan, X., \& Chen, M. (2001). Parental Involvement and Students' Academic Achievement: A Meta-Analysis. Educational Psychology Review, 13, 1-22. https://doi.org/10.1023/A:1009048817385

Farrington, C. A., Roderick, M., Allensworth, E., Ngaoka, J., Keyes, T. S., Johnson, D., \& Beechum, N. O. (2012). Teaching Adolescents to Become Learners: The Role of Noncognitive Factors in Shaping School Performance. Chicago, IL: Consortium on Chicago School Research, University of Chicago.

Fawcett, L. M., \& Gatron, A. F. (2005). The Effect of Peer Collaboration on Children's Problem-Solving Ability. British Journal of Education Psychology, 75, 157-169. https://doi.org/10.1348/000709904X23411

Feinstein, L., \& Symons, J. (1999). Attainment in Secondary School. Oxford Economic Papers, 51, 300-321. https://doi.org/10.1093/oep/51.2.300

Finn, D. J. (1989). Withdrawing from School. Review of Educational Research, 59, 117-142. https://doi.org/10.3102/00346543059002117

Finn, J. D., Fish, R. M., \& Scott, L. A. (2008). Educational Sequelae of High School Misbehavior. Journal of Educational Research, 101, 259-274. https://doi.org/10.3200/JOER.101.5.259-274

Frankenberg, E., \& Kotok, S. (2013). Demography and Educational Politics in the Subur- 
ban Marketplace. Peabody Journal of Education, 88, 112-126.

https://doi.org/10.1080/0161956X.2013.752628

Fraser, B. F., \& Walberg, H. J. (1991). Educational Environments: Evaluation, Antecedents and Consequences. London: Pergamon.

Furlong, A. (1986). Schools and the Structure of Female Occupational Aspirations. British Journal of Sociology of Education, 7, 367-377. https://doi.org/10.1080/0142569860070402

Gandara, P., \& Contreras, F. (2009). The Latino Education Crisis: The Consequences of Failed Social Policies. Cambridge, MA: Harvard University Press.

Garasky, S. (1995). The Effects of Family Structure on Educational Attainment-Do the Effects Vary by the Age of the Child? American Journal of Economics and Sociology, 54, 89-105. https://doi.org/10.1111/j.1536-7150.1995.tb02633.x

Garnier, H. E., Stein, J. A., \& Jacobs, J. A. (1997). The Process of Dropping Out of High School: A 19-Year Perspective. American Educational Research Journal, 34, 395-419. https://doi.org/10.3102/00028312034002395

Garton, A. E., \& Pratt, C. (2001). Peer Assistance in Children's Problem Solving. British Journal of Developmental Psychology, 19, 307-318. https://doi.org/10.1348/026151001166092

Glesmann, C., Krisberg, B., \& Marchionna, S. (2010). Youth in Gangs: Who Is at Risk? Oakland, CA: National Council on Crime and Delinquency.

Goleman, D. (1995). Emotional Intelligence. New York: Bantam Books.

Green, C. L., Walker, J. M. T., Hoover-Dempsey, K. V., \& Sandler, H. (2007). Parents' Motivations for Involvement in Children's Education: An Empirical Test of a Theoretical Model of Parental Involvement. Journal of Educational Psychology, 99, 532-544. https://doi.org/10.1037/0022-0663.99.3.532

Hanafin, J., \& Lynch, A. (2002). Peripheral Voices: Parental Involvement, Social Class and Educational Disadvantage. British Journal of Sociology of Education, 23, 35-49. https://doi.org/10.1080/01425690120102845

Haveman, R., Wolfe, B., \& Spaulding, J. (1991). Childhood Events and Circumstances Influencing High School Completion. Demography, 28, 133-157. https://doi.org/10.2307/2061340

Henecka, H. P. (2001). Sociology: Introducing Readings. Cambridge: Polity.

Hill, N. E., \& Taylor, L. C. (2004). Parental School Involvement and Children's Academic Achievement: Pragmatics and Issues. Current Directions in Psychological Science, 13, 161-164. https://doi.org/10.1111/j.0963-7214.2004.00298.x

Hochschild, J., \& Scovronick, N. (2003). The American Dream and the Public Schools. New York: Oxford University Press.

Houssemand, C. L., \& Meyers, R. (2013). The Role of Parenting in Dropping Out of School: Contributions and Limits of Qualitative Research Methods. Procedia-Social and Behavioural Sciences, 89, 523-528. https://doi.org/10.1016/j.sbspro.2013.08.887

Huffman, L. R., \& Speer, P. W. (2000). Academic Performance among At-Risk Children: The Role of Developmentally Appropriate Practices. Early Childhood Research Quarterly, 15, 167-184. https://doi.org/10.1016/S0885-2006(00)00048-X

Hunt, F. (2008). Dropping Out of Schools: A Cross Country Review of Literature. NUPEA, 7, 123-134.

Ingels, S. J., Scott, L. A., Lindmark, J. T., Frankel, M. R., \& Myers, S. L. (1992). National Education Longitudinal Study of 1988, First Follow-Up: Student Component Data File 
User's Manual (NCES 92-030). Washington DC: National Center for Education Statistics, U.S. Department of Education.

Jacob, B. A. (2001). Getting Tough? The Impact of High School Graduation Exams. Educational Evaluation and Policy Analysis, 23, 99-121. https://doi.org/10.3102/01623737023002099

Jeynes, W. H. (2007). The Relationship Between Parental Involvement and Urban Secondary School Student Academic Achievement: A Meta-Analysis. Urban Education, 42, 82-110. https://doi.org/10.1177/0042085906293818

Jimerson, R. S. (1999). On the Failure of Failure: Examining the Association between Early Grade Retention and Education and Employment Outcomes during Late Adolescence. Journal of School Psychology, 37, 243-272.

https://doi.org/10.1016/S0022-4405(99)00005-9

Johnson, D. W., \& Johnson, R. T. (1983). Social Interdependence and Perceived Academic and Personal Support in the Classroom. Journal of Social Psychology, 120, 77-82. https://doi.org/10.1080/00224545.1983.9712012

Johnson, D. W., \& Johnson, R. T. (1999). Learning Together and Alone: Cooperative, Competitive and Individualistic Learning. Boston, MA: Allyn and Bacon.

Johnson, D. W., Johnson, R. T., \& Anderson, D. (1983). Social Interdependence and Classroom Climate. Journal of Psychology, 114, 135-142. https://doi.org/10.1080/00223980.1983.9915406

Johnson, D. W., Johnson, R. T., \& Holubec, E. J. (1994). Cooperative Learning in the Classroom. Alexandria, VA: Association for Supervision and Curriculum Development.

Johnson, D. W., Johnson, R. T., Buckman, L. A., \& Richards, P. S. (1985). The Effect of Prolonged Implementation of Cooperative Learning on Social Support within the Classroom. Journal of Psychology, 119, 405-411. https://doi.org/10.1080/00223980.1985.10542911

Kainuwa, A., \& Yusuf, N. B. M. (2019). Influence of Socio-Economic and Educational Background of Parents on their Children's Education in Nigeria. IJSRP, 3, 34-47.

Kellaghan, T., Sloane, K., Alvarez, B., \& Bloom, B. S. (1993a). Involving Parents in Home Processes and Learning. The Home Environment and School Learning: Promoting Parental Involvement in the Education of Children. San Francisco, CA: Jossey-Bass.

Kellaghan, T., Sloane, K., Alvarez, B., \& Bloom, B. S. (1993b). The Home Environment and School Learning: Promoting Parental Involvement in the Education of Children. San Francisco, CA: Jossey-Bass.

King, R. (1987). Sex and Social Class Inequalities in Education: A Re-Examination. British Journal of Sociology of Education, 8, 287-303.

https://doi.org/10.1080/0142569870080304

Kober, N. (2001). What Special Problems Do Minority Students Face in Math? What Approaches Can Help Overcome Them? In N. Kober (Ed.), What We Know About Mathematics Teaching and Learning (pp. 22-27).

https://www.amazon.com/About-Mathematics-Teaching-Learning-EDTALK/dp/B000 SSLM42

Kotok, S., Ikoma, S., \& Bodovski, K. (2016). School Climate and Dropping Out of School in the Era of Accountability. American Journal of Education, 122, 569-599. https://doi.org/10.1086/687275

Lamb, M. (1995). The Consequences of INSET. ELT Journal, 49, 72-80. https://doi.org/10.1093/elt/49.1.72 
Lawrence, L. (1990). Language in Education: An Evaluation of the Teaching of Structure in Zambian Grade 8 Classes. Unpublished PhD Theses. Lusaka: University of Zambia.

Lempers, J. D., \& Clark, D. (1998). Family Economic Stress, Maternal and Paternal Support and Adolescent Distress. Journal of Adolescence, 13, 217-229. https://doi.org/10.1016/0140-1971(90)90015-Y

Lester, D., \& Miller, C. (1990). Depression and Suicidal Preoccupation in Teenagers. Personality and Individual Differences, 11, 421-422. https://doi.org/10.1016/0191-8869(90)90226-H

Levin, B. (2012). More High School Graduates: How Schools Can Save Students from Dropping Out. Thousand Oaks, CA: Corwin Sage Publications.

Lichter, D. F., Gretchen, T., Cornwall, D. J., \& Eggbeen, M. (1993). Harvesting Human Capital: Family Structure and Education among Rural Youth. Rural Sociology, 58, 53-75. https://doi.org/10.1111/j.1549-0831.1993.tb00482.x

Lloynd, C. B., Mete, C., \& Grant, M. J. (2009). The Implication of Changing Educational and Family Circumstances for Children's Grade Progression in Rural Pakistan, 1997-2004. Economics of Educational Review, 28, 152-160.

https://doi.org/10.1016/j.econedurev.2007.04.005

Lund, C. (2009). The Factors That Contribute to the U.S High School Dropout Rate. Sociology Analysis, 26, 334-357.

Matsagouras, I., \& Voulgaris, S. (2006). The Psychological Climate of School Classroom in Greek Primary Schools. In A. Trillianos (Ed.), Acknowledgement: In Honour of Professor T. G. Exarchakos (pp. 315-343). Athens: National \& Kapodistrian University of Athens.

Menheere, A., \& Edith, H. H. (2012). Parental Involvement in Children's Education: A Review Study about Effect of Parental Involvement on Children's School Education with a Focus on the Position of Illiterate Parents. The Journal of the European Teacher Education Network, 6, 83-97.

Mitchell, R. (1988). Communicative Language Teaching in Practice. London: CILT.

Murphy, J. (1981). Disparity and Inequality in Education: The Crippling Legacy of Coleman. British Journal of Sociology of Education, 2, 61-70. https://doi.org/10.1080/0142569810020104

Neuman, S. B., \& Dickinson, D. K. (2000). Handbook of Early Literacy Research. New York: The Guilford Press.

Nunan, D. (1987). Communicative Language Teaching: Making It Work. ELT Journal, 41, 136-145. https://doi.org/10.1093/elt/41.2.136

Ogbu, J. U. (1987). Variability in Minority School Performance: A Problem in Search of an Explanation. Anthropology and Education Quarterly, 18, 312-334.

Oreopoulous, P., Page, M., \& Stevens, A. (2006). The Intergenerational Effects of Compulsory Schooling. Journal of Labour Economics, 24, 729-760. https://doi.org/10.1086/506484

Osgood, D. W., Foster, E. M., \& Courtney, M. E. (2010). Vulnerable Populations and the Transition to Adulthood. The Future of Children, 20, 209-229. https://doi.org/10.1353/foc.0.0047

Ou, S.-R., Mersky, J., Reynolds, A. J., \& Kohler, K. M. (2007). Alterable Predictors of Educational Attainment, Income, and Crime: Findings from an Inner-City Cohort. Social Service Review, 81, 85-128. https://doi.org/10.1086/510783

Perreira, K. M., Harris, K. M., \& Lee, D. (2006). Making It in America: High School Completion by Immigrant and Native Youth. Demography, 43, 511-536. 
https://doi.org/10.1353/dem.2006.0026

Phares, J. E. (2010). Introduction to Psychology. London: Scott Foresman.

Pianta, R. L. (1999). Enhancing Relationships between Children and Teachers. Washington DC: American Psychological Association. https://doi.org/10.1037/10314-000

Pomerantz, E. M., Moorman, E. A., \& Litwack, S. D. (2007). The How, Whom, and Why of Parents' Involvement in Children's Academic Lives: More Is Not Always Better. Review of Educational Research, 77, 373-410. https://doi.org/10.3102/003465430305567

Pong, S. L., \& Ju, D. B. (2000). The Effects of Change in Family Structure and Income on Dropping Out of Middle and High School. Journal of Family Issues, 21, 147-169. https://doi.org/10.1177/019251300021002001

Ratcliffe, C., \& McKernan, S. M. (2010). Childhood Poverty Persistence: Facts and Consequences. Washington DC: Urban Institute.

Ratelle, C. F., Guay, F., Vallerand, R. J., Larose, S., \& Senecal, C. (2007). Autonomous, Controlled and Amotivated Types of Academic Motivation: A Person-Oriented Analysis. Journal of Educational Psychology, 99, 734-746.

https://doi.org/10.1037/0022-0663.99.4.734

Reese, L., Garnier, H., Gallimore, R., \& Goldenberg, C. (2000). Longitudinal Analysis of the Antecedents of Emergent Spanish Literacy and Middle-School English Reading Achievement of Spanish-Speaking Students. American Educational Research Journal, 37, 633-662. https://doi.org/10.3102/00028312037003633

Reynolds, A. J., Ou, S.-R., \& Topitzes, J. W. (2004). Paths of Effects of Early Childhood Intervention on Educational Attainment and Delinquency: A Confirmatory Analysis of the Chicago Child-Parent Centers. Child Development, 75, 1299-1328.

https://doi.org/10.1111/j.1467-8624.2004.00742.x

Roser, L. N., Hoffman, V. J., \& Farest, C. (1990). Language, Literature and At-Risk Children. The Reading Teacher, 34, 554-559.

Rotermund, S. L. (2010). The Role of Psychological Antecedents and Student Engagement in a Process Model of High School Dropout. PhD Dissertation, Santa Barbara, CA: University of California.

Rumberger, R. W. (1995). Dropping Out of Middle School: A Multilevel Analysis of Students and Schools. American Educational Research Journal, 32, 583-625. https://doi.org/10.3102/00028312032003583

Rumberger, R. W. (2011). Dropping Out: Why Students Drop Out of High School and What Can Be Done about It. Cambridge, MA: Harvard University Press. https://doi.org/10.4159/harvard.9780674063167

Rumberger, R. W., \& Lim, S. A. (2008). Why Students Drop Out of School: A Review of 25 Years of Research. Santa Barbara, CA: California Dropout Research Project.

Rumberger, R. W., \& Thomas, S. L. (2000). The Distribution of Dropout and Turnover Rates among Urban and Suburban High Schools. Sociology of Education, 73, 39-67. https://doi.org/10.2307/2673198

Ryle, R. (2011). Questioning Gender: A Sociological Exploration. London: Sage Publications.

Samaha, N. V., \& DeLisi, R. (2000). Peer Collaboration on a Nonverbal Reasoning Task by Urban, Minority Systems. Journal of Experimental Education, 69, 5-21. https://doi.org/10.1080/00220970009600646

Samal, R. (2012). Parents' Attitudes towards Schooling and Education. Project Report submitted to Department of Humanities and Social Sciences. For the Partial Fulfillment of the Requirement in Master's Degree in Development Studies, National Insti- 
tute of Technology Rourkela.

Sanders, M. G., \& Epstein, J. L. (2000). Building School-Family-Community Partnerships in Middle and High School. In M. G. Sanders (Ed.), School Students Placed at Risk: Research, Policy, and Practice in the Education of Poor and Minority Adolescents (pp. 339-361). Hillsdale, NJ: Lawrence Erlbaum Associates Publishers.

Schargel, F. P., \& Smink, J. (2001). Strategies to Help Solve our School Dropout Problem. New York: Eye on Publication.

Seltzer, J. A. (1994). Consequences of Marital Dissolution for Children. Annual Review of Sociology, 20, 235-266. https://doi.org/10.1146/annurev.so.20.080194.001315

Silva, C., \& Kucer, B. S. (1997). Expanding Curricular Conversations through Unification, Diversity and Access. Language Arts, 74, 26-32.

Simba, N. O., Agak, J. O., \& Kabuka, E. K. (2016). Impact of Discipline on Academic Performance of Pupils in Public Primary Schools in Muhoroni Sub-County, Kenya. Journal of Education and Practice, 7, 164-173.

Singh, A. K., \& Sinha, M. K. (2002). Personality Characteristics of Socially Advantaged and Socially Disadvantaged Children. Indian Journal of Psychometry \& Education, 21, 81-86.

Snyder, T. D., \& Dillow, S. A. (2011). Status and Trends in the Education of Racial and Ethnic Groups. Digest of Education Statistics (NCES 2011), 373-410.

Spera, C. (2005). A Review of the Relationship among Parenting Practices, Parenting Styles, and Adolescent School Achievement. Educational Psychological Review, 17, 125-146. https://doi.org/10.1007/s10648-005-3950-1

Srivastava, P. (2012). Psychological Factors of Dropout Students in Elementary and Middle Schools. Rajeev Gandhi Shiksha Mission Project, SOS in Psychology: Pt Ravishanker Shukle University Raipur.

Steinberg, L., Dornbusch, S. M., \& Brown, B. (1992). Ethnic Differences in Adolescent Achievement: An Ecological Perspective. American Psychologist, 47, 723-729. https://doi.org/10.1037/0003-066X.47.6.723

Stone, S. (2006). Correlates of Change in Student Reported Parent Involvement in Schooling: A New Look at the National Education Longitudinal Study of 1988. American Journal of Orthopsychiatry, 76, 518-530. https://doi.org/10.1037/0002-9432.76.4.518

Subrahmanyam, G. (2016). Gender Perspectives on Causes and Effects of School Dropouts from Primary and Secondary Education in Developing Countries-An Overview. Stockholm: Swedish International Development Cooperation Agency.

Tabachnick, B. G., \& Fidell, L. S. (2006). Using Multivariate Statistics. New York: Harper Collins.

Tansel, A. (2002). Determinants of School Attainment of Boys and Girls in Turkey: Individual, Household and Community Factors. Economics of Education Review, 21, 455-470. https://doi.org/10.1016/S0272-7757(01)00028-0

Teachman, J. D., Paasch, K., \& Carver, K. (1997). Social Capital and the Generation of Human Capital. Social Forces, 75, 1343-1359. https://doi.org/10.2307/2580674

Teklemariam, A. N. (2011). Socio-Cultural and Economic Factors Affecting Primary Education of Masaai Girls in Loitokitok District, Kenya. Western Journal of Black Studies, 2, 13-25.

Tenbusch, M. (2016). The Jonathan Effect: Helping Kids and Schools Win the Battle against Poverty. Downers Grove,, IL: IVP Books. 
Thapa, A., Cohen, J., Guffey, S., \& Higgins-D’Alessandro, A. (2013). A Review of School Climate Research. Review of Educational Research, 83, 357-383. https://doi.org/10.3102/0034654313483907

Tomlinson, S. (1991). Teachers and Parents: Home-School Partnerships. London: Institute for Public Policy Research.

Toomey, D. (1989). Linking Class and Gender Inequality: The Family and Schooling. British Journal of Sociology of Education, 10, 389-402. https://doi.org/10.1080/0142569890100401

Trang, T., \& Van der Velden, R. K. W. (2011). Early School Leaving in the Netherlands: The Role of Family Resources, School Composition and Background Characteristics in Early School Leaning in Lower Secondary Education. Irish Educational Studies, 30, 45-62. https://doi.org/10.1080/03323315.2011.535975

Underwood, J., Underwood, G., \& Wood, D. (2000). When Does Gender Matter?: Interactions during Computer-Based Problem Solving. Learning and Instruction, 10, 447-462. https://doi.org/10.1016/S0959-4752(00)00008-6

UNICEF (2014). Thematic Report 2013: Basic Education and Gender Equality. New York: UNICEF.

Viadero, D. (2001). The Dropout Dilemma. Research Hindered by Lack of Uniform Way to Count Students Who Quit School. Education Week, 7, 23-45.

Warren, J. R., LePore, P. C., \& Mare, D. R. (2000). Employment during High School: Consequences for Students' Grades in Academic Courses. American Educational Research Journal, 37, 943-969. https://doi.org/10.3102/00028312037004943

Weiner, G. (1986). Feminist Education and Equal Opportunities: Unity or Discord? British Journal of Sociology of Education, 7, 265-274. https://doi.org/10.1080/0142569860070302

West, A., \& Pennell, H. (2003). Underachievement in Schools. London: Routledge. https://doi.org/10.4324/9780203441206

Worswick, C. (2001). School Performance of the Children of Immigrants in Canada, 1994-98 (p. 178). Department of Economics, Carleton University and Family and Labour Studies Statistics Canada.

Xanthacou, Y., Babalis, Th., \& Stavrou, N. (2013). The Role of Parental Involvement in Classroom Life in Greek Primary and Secondary Education. Psychology, 4, 118-123. https://doi.org/10.4236/psych.2013.42017

Zimmerman, B. J. (2008). Investigating Self-Regulation and Motivation: Historical Background, Methodological Developments, and Future Prospects. American Educational Research Journal, 45, 166-183. https://doi.org/10.3102/0002831207312909

Zullig, K., Koopman, T., Patton, J., \& Ubbes, V. (2010). School Climate: Historical Review, Instrument Development and School Assessment. Journal of Psychoeducational Assessment, 28, 139-152. https://doi.org/10.1177/0734282909344205 